\title{
RESEARCH
}

Open Access

\section{Prevalence of dyslipidemia and gene polymorphisms of $A B C B 1$ and SLCO1B1 in Han, Uygur, Kazak, Hui, Tatar, Kirgiz, and Sibe populations with coronary heart disease in Xinjiang, China}

Tingting Wang ${ }^{1,2+} \mathbb{B}$, Li Sun ${ }^{1,2+}$, Li Xu ${ }^{3}$, Ting Zhao ${ }^{2}$, Jie Feng ${ }^{2}$, Luhai Yu', Jianhua Wu ${ }^{1,2^{*}}$ and Hongjian $\mathrm{Li}^{2^{*}}$

\begin{abstract}
Background: Dyslipidemia is a predisposing factor for coronary heart disease (CHD). High-intensity statin therapy is recommended as secondary prevention. ABCB1 and SLCO1B1 genes influence the efficacy and safety of statins. Xinjiang is a multi-ethnic area; however, little is known about the prevalence of dyslipidemia and gene polymorphisms of $A B C B 1$ and SLCO1B1 in minority groups with CHD.

Objective: To measure levels of lipid and apolipoprotein and the prevalence of dyslipidemia and gene polymorphisms of ABCB1, SLCO1B1 in Han, Uygur, Kazak, Hui, Tatar, Kirgiz, and Sibe populations with CHD in Xinjiang.

Methods: This descriptive retrospective study compares lipid levels in ethnic groups using Kruskal-Wallis test or analysis of variance. The study compared gene polymorphisms and the prevalence of dyslipidemia among different ethnic groups using the chi-square test. The lipid profiles in plasma were measured before lipid-lowering therapy using commercially available kits. Genotyping of SLCO1B1 and ABCB1 variants was performed using sequencing by hybridization.
\end{abstract}

\footnotetext{
*Correspondence: 1520580268@qq.com; 331689583@qq.com

${ }^{\dagger}$ Tingting Wang and Li Sun contributed equally to this work and should be considered co-first authors.

'Department of Pharmacy, People's Hospital of Xinjiang Uygur Autonomous Region, No. 91 Tianchi Road, Tianshan District, Urumqi 830001, Xinjiang,

China

${ }^{2}$ Institute of Clinical Pharmacy, People's Hospital of Xinjiang Uygur

Autonomous Region, No. 91 Tianchi Road, Tianshan District, Urumqi 830001, Xinjiang, China

Full list of author information is available at the end of the article
}

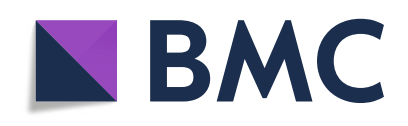

(c) The Author(s). 2021 Open Access This article is licensed under a Creative Commons Attribution 4.0 International License, which permits use, sharing, adaptation, distribution and reproduction in any medium or format, as long as you give appropriate credit to the original author(s) and the source, provide a link to the Creative Commons licence, and indicate if changes were made. The images or other third party material in this article are included in the article's Creative Commons licence, unless indicated otherwise in a credit line to the material. If material is not included in the article's Creative Commons licence and your intended use is not permitted by statutory regulation or exceeds the permitted use, you will need to obtain permission directly from the copyright holder. To view a copy of this licence, visit http://creativecommons.org/licenses/by/4.0/. The Creative Commons Public Domain Dedication waiver (http://creativecommons.org/publicdomain/zero/1.0/) applies to the data made available in this article, unless otherwise stated in a credit line to the data. 
Results: A total of 2218 patients were successfully screened, including 1044 Han, 828 Uygur, 113 Kazak, 138 Hui, 39 Tatar, 36 Kirgiz, and 20 Sibe patients. The overall mean age was $61.8 \pm 10.8$ years, and $72.5 \%$ of participants were male. Dyslipidemia prevalence in these ethnic groups was 42.1, 49.8, 52.2, 40.6, 48.7, 41.7, and 45.0\%, respectively. The prevalence of dyslipidemia, high total cholesterol (TC), high triglycerides (TG), and high low density lipoprotein cholesterol (LDL-C) differed significantly among the groups $(P=0.024 ; P<0.001 ; P<0.001 ; P<0.001$, respectively). For the Han group, high LDL-C, high TC, and high TG prevalence differed significantly by gender $(P=0.001, P=$ $0.022, P=0.037$, respectively). The prevalence of high TC, high TG, and low high density lipoprotein cholesterol (HDL-C) differed significantly by gender in the Uygur group $(P=0.006, P=0.004, P<0.001$, respectively). The prevalence of high TC in Hui patients significantly differed by gender $(P=0.043)$. These findings suggest that polymorphisms in $A B C B 1$ and $C 3435 T$ differ significantly across ethnicities $(P<0.001)$.

Conclusions: The prevalences of dyslipidemia, high TC, high TG, and high LDL-C in Han, Uygur, Kazak, Hui, Tatar, Kirgiz, and Sibe CHD patients in Xinjiang differed concerning ethnicity. Ethnic, gender, and lifestyle were the key factors that affected the lipid levels of the population. The prevalence of polymorphisms of $A B C B 1$ and C3435T significantly differed across ethnicities. These findings will aid the selection of precision lipid-lowering medications and prevention and treatment of CHD according to ethnicity in Xinjiang.

Keywords: $A B C B 1, S L C O 1 B 1$, lipid, ethnic, coronary heart disease, dyslipidemia

\section{Background}

There is a strong relationship between dyslipidemia and coronary heart disease (CHD) [1-3], which is emerging as the major cause of mortality in China [4]. Dyslipidemia tends to increase levels of plasma triglycerides (TG), total cholesterol (TC), and low-density lipoprotein cholesterol (LDL-C) and reduces levels of high-density lipoprotein cholesterol (HDL-C) [5]. Statins are commonly prescribed for primary and secondary prevention of CHD [6]. The ATP-binding cassette transporter B1 gene $(A B C B 1)$ encodes $\mathrm{P}$-glycoprotein $(\mathrm{P}$-gp), which determines the concentration of medications that reach target tissues, and statins are among its substrates [7]. The solute carrier organic anion transporter 1B1 gene (SLCO1B1) is thought to play a critical role in statin transport into hepatocytes [8, 9]. SLCO1B1 and $A B C B 1$ modulate stain absorption and ultimately influence their safety and efficacy. Therefore, the present study was carried out to measure lipid profiles and polymorphisms of SLCO1B1 and $A B C B 1$ in patients with CHD in Han, Uygur, Kazak, Hui, Tatar, Kirgiz, and Sibe ethnic groups and compare the differences between them.

\section{Methods}

\section{Patients and design}

This was a descriptive retrospective study conducted to compare lipid levels and gene polymorphisms in ethnic groups. The Han, Uygur, Kazak, Hui, Tatar, Kirgiz, and Sibe populations are among 56 ethnic groups of China; the Uygur, Kazak, Tatar, Kirgiz, and Sibe groups primarily live in Xinjiang province.

Unrelated patients of various ethnicities from People's Hospital of Xinjiang Uygur Autonomous Region (PHOXUAR) were enrolled from April 5, 2017, to
February 10, 2021. Newly diagnosed CHD patients $\geq 18$ years old were recruited. Lipids levels were measured before initiation of lipid-lowering therapy. All subjects were required to have a complete lipid profile available. Exclusion criteria included pregnancy, autoimmune disease, hematologic disease, cancer, liver disease, renal disease, thyroid disease, or treatment with lipid-lowering medications before or during blood collection. The diagnosis of CHD, dyslipidemia, hypertension, diabetes mellitus, and the classification of smoking and alcohol intake are shown in Supplementary Material 1. The study was approved by the ethics committees of PHOXUAR.

\section{Lipid and apolipoprotein measurements}

Blood samples for the evaluation of lipid and apolipoprotein levels were obtained from patients between 7 a.m. and 11 a.m., after at least $12 \mathrm{~h}$ of fasting. Plasma levels of TG, TC, HDL-C, LDL-C, small dense low density lipoprotein (sdLDL), apolipoprotein B-100 (ApoB), apolipoprotein A1 (ApoA1) and apolipoproteins E (ApoE) were estimated using commercially available kits (Abbott Laboratories, Illinois, USA) and an Abbott i1000 auto analyzer (Abbott Laboratories, Illinois, USA).

\section{Genotyping}

Whole blood samples were collected from a peripheral vein, and were collected in vacuum tubes containing EDTA (BD, New Jersey, USA), and were stored at $-20^{\circ} \mathrm{C}$ before analysis. Genomic DNA was extracted using the Puregene Blood Core Kit (Huaxia Times, Beijing, China) from blood samples. SLCO1B1 T521C (rs4149056), $A B C B 1$ G2677T (rs2032582) and $A B C B 1$ C3435T (rs1045642) were genotyped using sequencing by 
hybridization (Xi'an Tianlong Science \& Technology Co Ltd, Xi'an, China).

\section{Statistical analysis}

Categorical variables were expressed as patient numbers and percentages. Continuous variables were expressed as means with standard deviations. Age, body mass index (BMI), lipid and apolipoprotein levels across ethnic groups were compared using one-way analysis of variance and the Kruskal-Wallis test. The alleles, genotype frequencies, the prevalence of dyslipidemia, and other demographic characteristics among different ethnic groups were compared using the chi-square test. The distributions of genotypes were assessed for deviation from the Hardy-Weinberg equilibrium (HWE) using the chi-square test. $P<0.05$ was considered statistically significant. All statistical analyses were carried out using SPSS 19.0 (version 4.0.100.1124, SPSS Inc, USA).

\section{Results}

\section{Demographic characteristics}

Of 2292 individuals selected, 2218 were successfully screened, including 1044 Han, 828 Uygur, 113 Kazak, 138 Hui, 39 Tatar, 36 Kirgiz, and 20 Sibe patients. There were 74 patients excluded, including 19 (0.8\%) patients with renal diseases,16 (0.7\%) with liver diseases, 3 (0.1\%) with autoimmune diseases, $3(0.1 \%)$ with neoplasms, and $33(1.4 \%)$ received lipid-lowering therapy before blood collection. The mean age was $61.8 \pm 10.8$ years (range: $28-77$ years), and $72.5 \%$ were male. The age, BMI, alcohol intake, hypertension, and diabetes mellitus differed significantly across ethnicities $(P<0.001, P=0.002, P=0.008, P<$ 0.001 , and $P<0.001$, respectively). The age of the Han group $(63.1 \pm 11.4$ years $)$ was significantly older than Uygur (60.6 \pm 10.0 years), Kazak (59.3 \pm 10.1 years), and Kirgiz groups (57.5 $\pm 9.9, P<0.05$ years). The BMIs of Han, Hui, and Sibe groups $(25.5 \pm 3.0$, $25.0 \pm 3.2$, and $26.0 \pm 3.9 \mathrm{~kg} / \mathrm{m}^{2}$, respectively) were significantly lower than those of the Uygur, Kazak, and Tatar groups $(28.8 \pm 3.9,28.3 \pm 4.3$, and $28.1 \pm$ $4.3 \mathrm{~kg} / \mathrm{m}^{2}$, respectively; $P=0.002$ ).

Hypertension was most prevalent in all ethnic groups (all $>50 \%$ ). The prevalences in Kazak and Tatar groups were higher than other ethnic groups $(80.5 \%$ and $74.4 \%$, respectively, $P<0.001)$. The prevalence of diabetes mellitus in the Uygur and Kazak groups was higher than Han, Kirgiz, and Sibe groups $(P<0.001)$, and the prevalence was lowest in the Sibe group (20.0\%). The demographic characteristics of all patients are summarized in Table 1.

\section{Lipid and apolipoprotein levels}

Mean serum levels of LDL-C, HDL-C, TC, TG, sdLDL, ApoA1, ApoB, and ApoE differed significantly among ethnicities $(P=0.025 ; P=0.014 ; P<0.001 ; P$ $=0.032 ; P=0.04 ; P=0.027, P=0.001 ; P=0.001$, respectively). The mean LDL-C level was significantly higher in the Kazak group $(3.18 \pm 0.92 \mathrm{mM})$ than the other ethnic groups $(P<0.05)$. The Sibe group $(2.64$ $\pm 0.74 \mathrm{mM})$ had the lowest mean LDL-C level. The mean HDL-C level was significantly higher in the Han $(0.95 \pm 0.25 \mathrm{mM})$, Kirgiz $(0.95 \pm 0.29 \mathrm{mM})$, and Sibe groups $(0.96 \pm 0.22 \mathrm{mM})$ and lower in the Uygur group $(0.87 \pm 0.22 \mathrm{mM})$ than the other ethnic groups $(P=0.014)$.

The Han, Uygur, Kazak, and Tatar groups had significantly higher TG levels than Hui, Kirgiz, and Sibe groups $(P<0.001)$. The Han, Uygur, Kazak, and Hui groups had significantly higher TC levels than the Tatar, Kirgiz, and Sibe groups $(P=0.032)$. The sdLDL level was highest in the Uygur group (377.5 \pm $149.5 \mathrm{mg} / \mathrm{L}$ ) and lowest in the Kirgiz group (311.3 \pm $114.0 \mathrm{mg} / \mathrm{L}$ ). The Han, Tatar, and Sibe groups had significantly higher ApoA1 levels than other ethnic groups except for the Kazak group $(P=0.027)$. The Kirgiz group had the lowest ApoB $(0.68 \pm 0.23 \mathrm{mg} /$ $\mathrm{dL})$ and ApoE levels $(2.75 \pm 0.80 \mathrm{mg} / \mathrm{dL})$. The lipid and apolipoprotein levels of different ethnic CHD groups are summarized in Table 2.

Table 1 Demographic characteristics of the population under study

\begin{tabular}{|c|c|c|c|c|c|c|c|c|c|}
\hline Demographic characteristics & $\begin{array}{l}\text { Overall } \\
(n=2218)\end{array}$ & $\begin{array}{l}\text { Han } \\
(n=1044)\end{array}$ & $\begin{array}{l}\text { Uygur } \\
(n=828)\end{array}$ & $\begin{array}{l}\text { Kazak } \\
(n=113)\end{array}$ & $\begin{array}{l}\text { Hui } \\
(n=138)\end{array}$ & $\begin{array}{l}\text { Tatar } \\
(n=39)\end{array}$ & $\begin{array}{l}\text { Kirgiz } \\
(n=36)\end{array}$ & $\begin{array}{l}\text { Sibe } \\
(n=20)\end{array}$ & $P$ value \\
\hline Male sex, n (\%) & $1609(72.5)$ & $754(72.2)$ & $609(73.6)$ & $78(69.0)$ & 96 (69.6) & $28(71.8)$ & $28(77.8)$ & $16(80.0)$ & 0.827 \\
\hline Age (years, mean $\pm S D$ ) & $61.8 \pm 10.8$ & $63.1 \pm 11.4^{a}$ & $60.6 \pm 10.0^{b}$ & $59.3 \pm 10.1^{b}$ & $62.1 \pm 10.0^{a b}$ & $60.6 \pm 11.5^{a b}$ & $57.5 \pm 9.9^{b}$ & $61.4 \pm 11.2^{\mathrm{ab}}$ & $<0.001$ \\
\hline BMI $\left(\mathrm{kg} / \mathrm{m}^{2}\right.$, mean $\left.\pm \mathrm{SD}\right)$ & $28.0 \pm 6.9$ & $25.5 \pm 3.0^{a}$ & $28.8 \pm 3.9^{b}$ & $28.3 \pm 4.3^{b}$ & $25.0 \pm 3.2^{\mathrm{a}}$ & $28.1 \pm 4.3^{b}$ & $27.2 \pm 6.8^{a b}$ & $26.0 \pm 3.9^{a}$ & 0.002 \\
\hline Alcohol intake, n (\%) & $552(24.9)$ & $291(27.9)^{a}$ & $186(22.5)^{a b}$ & $30(26.5)^{a b}$ & $19(13.8)^{b}$ & $10(25.6)^{a b}$ & $11(30.6)^{a b}$ & $5(25.0)^{a b}$ & 0.008 \\
\hline Smoking, n (\%) & 869 (39.2) & $418(40.0)$ & $311(37.6)$ & $48(42.5)$ & $49(35.5)$ & $17(43.6)$ & $18(50.0)$ & $8(40.0)$ & 0.593 \\
\hline Hypertension & $1416(63.8)$ & $630(60.3)^{a}$ & $562(67.9)^{a}$ & $91(80.5)^{b}$ & $77(55.8)^{a}$ & $29(74.4)^{a b}$ & $20(55.6)^{a}$ & $11(55.0)^{a}$ & $<0.001$ \\
\hline Diabetes mellitus & $842(38.0)$ & $343(32.9)^{a}$ & $367(44.3)^{b}$ & $53(46.9)^{b}$ & $52(37.7)^{a b}$ & $14(35.9)^{a b}$ & $9(25.0)^{a}$ & $4(20.0)^{a}$ & $<0.001$ \\
\hline
\end{tabular}

BMI Body mass index; $a, b$ and $c$ denote the difference of ethnic groups by $x^{2}$ test at 0.05 
Table 2 Lipid and apolipoprotein levels in seven ethnic groups

\begin{tabular}{|c|c|c|c|c|c|c|c|c|c|}
\hline Variable & $\begin{array}{l}\text { Overall } \\
(n=2218)\end{array}$ & $\begin{array}{l}\text { Han } \\
(n=1044)\end{array}$ & $\begin{array}{l}\text { Uygur } \\
(n=828)\end{array}$ & $\begin{array}{l}\text { Kazak } \\
(n=113)\end{array}$ & $\begin{array}{l}\text { Hui } \\
(n=138)\end{array}$ & $\begin{array}{l}\text { Tatar } \\
(n=39)\end{array}$ & $\begin{array}{l}\text { Kirgiz } \\
(n=36)\end{array}$ & $\begin{array}{l}\text { Sibe } \\
(n=20)\end{array}$ & $P$ value \\
\hline LDL-C(mg/dL) & $116.8 \pm 36.7$ & $114.8 \pm 38.3^{a}$ & $116.8 \pm 34.4^{a}$ & $122.9 \pm 35.6^{b}$ & $116.0 \pm 38.7^{\mathrm{a}}$ & $113.3 \pm 35.6^{a}$ & $105.2 \pm 32.1^{c}$ & $102.1 \pm 28.6^{c}$ & 0.025 \\
\hline $\mathrm{HDL}-\mathrm{C}(\mathrm{mg} / \mathrm{dL})$ & $35.6 \pm 9.3$ & $36.7 \pm 9.7^{\mathrm{a}}$ & $33.6 \pm 8.5 b$ & $35.2 \pm 8.5^{a b}$ & $35.2 \pm 8.9^{a b}$ & $34.8 \pm 11.2^{\mathrm{ab}}$ & $36.7 \pm 11.2^{\mathrm{a}}$ & $37.1 \pm 8.5^{\mathrm{a}}$ & 0.014 \\
\hline $\mathrm{TG}(\mathrm{mg} / \mathrm{dL})$ & $175.4 \pm 109.0$ & $175.4 \pm 120.5^{a}$ & $176.3 \pm 100.1^{a}$ & $179.0 \pm 125.8^{a}$ & $165.7 \pm 72.7^{b}$ & $171.9 \pm 41.6^{\mathrm{a}}$ & $163.0 \pm 73.5^{b}$ & $165.7 \pm 86.8^{b}$ & $<0.001$ \\
\hline $\mathrm{TC}(\mathrm{mg} / \mathrm{dL})$ & $195.6 \pm 53.0$ & $193.7 \pm 52.2^{a}$ & $196.8 \pm 40.6^{\mathrm{a}}$ & $199.9 \pm 38.7^{\mathrm{a}}$ & $191.0 \pm 44.5^{b}$ & $196.0 \pm 41.8^{a}$ & $193.7 \pm 47.9^{b}$ & $189.4 \pm 41.4^{b}$ & 0.032 \\
\hline sdLDL(mg/L) & $361.8 \pm 149.5$ & $352.0 \pm 116.2^{a}$ & $377.5 \pm 149.5^{b}$ & $359.5 \pm 153.7^{\mathrm{a}}$ & $343.5 \pm 119.0^{a}$ & $336.6 \pm 119.1^{\text {ac }}$ & $311.3 \pm 114.0^{c}$ & $303.7 \pm 81.3^{c}$ & 0.04 \\
\hline ApoA1 (g/L) & $1.18 \pm 0.22$ & $1.21 \pm 0.23^{\mathrm{a}}$ & $1.14 \pm 0.21^{b}$ & $1.18 \pm 0.20 \mathrm{ab}$ & $1.09 \pm 0.23^{b}$ & $1.25 \pm 0.29^{a}$ & $1.10 \pm 0.25^{b}$ & $1.27 \pm 0.16^{\mathrm{a}}$ & 0.027 \\
\hline ApoB (mg/dL) & $0.82 \pm 0.25$ & $0.82 \pm 0.26^{a}$ & $0.83 \pm 0.23^{a}$ & $0.82 \pm 0.22^{a}$ & $0.81 \pm 0.21^{\mathrm{a}}$ & $0.76 \pm 0.22 \mathrm{ab}$ & $0.68 \pm 0.23^{b}$ & $0.73 \pm 0.21 \mathrm{ab}$ & 0.001 \\
\hline ApoE (mg/dL) & $3.13 \pm 1.13$ & $3.24 \pm 1.22^{a}$ & $3.05 \pm 1.07^{b}$ & $2.91 \pm 1.12^{b}$ & $3.12 \pm 0.96^{\mathrm{ab}}$ & $2.90 \pm 0.75^{\mathrm{ab}}$ & $2.75 \pm 0.80^{b}$ & $2.93 \pm 1.06^{\mathrm{ab}}$ & 0.001 \\
\hline
\end{tabular}

TG Triglycerides, LDL-C Low density lipoprotein cholesterol, HDL-C High density lipoprotein cholesterol, $T C$ Total cholesterol, sdLDL Small dense low density lipoprotein, ApoA1 Apolipoprotein A1, ApoB Apolipoprotein B-100, ApoE Apolipoproteins E; a, b and c denote the difference of ethnic groups by $\mathrm{X}^{2}$ test at 0.05

\section{Prevalence of dyslipidemia and high TC, high TG, high LDL-C, and low HDL-C}

As shown in Table 3 and Figure 1, the prevalence of overall dyslipidemia, high TC, high TG, and high LDL$\mathrm{C}$, differed significantly across the seven ethnicities $(P=$ $0.024 ; P<0.001 ; P<0.001 ; P<0.001$, respectively). However, there was no significant difference in low HDL-C $(P=0.663)$. There were $440,412,59,56,19,15$, and nine patients in the Han, Uygur, Kazak, Hui, Tatar, Kirgiz, and Sibe groups with dyslipidemia, respectively, giving prevalences of 42.1, 49.8, 52.2, 40.6, 48.7, 41.7 and $45.0 \%$, respectively. The prevalences of dyslipidemia in the Uygur and Kazak groups were significantly higher than Han, Hui, and Kirgiz groups $(P=0.024)$. The prevalences of high LDL-C, high TC, high TG, and in the Kazak group were highest $(30.1 \%, 30.1 \%$, and $46.9 \%$, respectively). High TC and high TG prevalences in the Kirgiz group were the lowest $(11.1 \%$, and $22.2 \%$, respectively). The prevalence of high $\mathrm{LDL}-\mathrm{C}$ was lowest in the Sibe group (10.0\%). The TC levels in the high TC group, the TG level in the high TG group, the LDL-C levels in the high LDL-C group, and the HDL-C level in the low HDL-C group are summarized in Table 3.

\section{Gender distribution of dyslipidemia}

There was no significant effect of gender on the overall prevalence of dyslipidemia across ethnic groups (all $P>$ 0.05). For the Han group, the prevalence of high TC and high LDL-C were significantly higher in males than females $(P=0.022, P=0.001$, respectively), whereas that the prevalence of high TG was significantly lower in males than females $(P=0.037)$. For the Uygur group, the prevalences of high TC and high TG were significantly higher in males than females $(P=0.006, P=$ 0.004 , respectively), whereas that the prevalence of low HDL-C was significantly higher in females than males $(P$

Table 3 Comparisons of prevalence and lipid levels of dyslipidemia, high TC, high TG, high LDL-C, and low HDL-C

\begin{tabular}{|c|c|c|c|c|c|c|c|c|c|c|c|c|c|c|c|c|}
\hline \multirow[t]{2}{*}{ Variable } & \multirow[t]{2}{*}{$\begin{array}{l}\text { Overall } \\
(n=2218)\end{array}$} & \multicolumn{2}{|c|}{$\operatorname{Han}(n=1044)$} & \multicolumn{2}{|c|}{$\begin{array}{l}\text { Uygur } \\
(n=828)\end{array}$} & \multicolumn{2}{|c|}{$\begin{array}{l}\text { Kazak } \\
(n=113) \\
\end{array}$} & \multicolumn{2}{|c|}{ Hui $(n=138)$} & \multicolumn{2}{|c|}{ Tatar $(n=39)$} & \multicolumn{2}{|c|}{ Kirgiz $(n=36)$} & \multicolumn{2}{|c|}{ Sibe $(n=36)$} & \multirow[t]{2}{*}{$\begin{array}{l}P \\
\text { value }\end{array}$} \\
\hline & & $\begin{array}{l}\mathrm{n}, \\
(\mathrm{n} \%)\end{array}$ & $\begin{array}{l}\text { level } \\
\text { (mg/ } \\
\mathrm{dL})\end{array}$ & $\begin{array}{l}\text { n, } \\
(n \%)\end{array}$ & $\begin{array}{l}\text { level } \\
\text { (mg/ } \\
\mathrm{dL})\end{array}$ & $\begin{array}{l}\mathrm{n}, \\
(\mathrm{n} \%)\end{array}$ & $\begin{array}{l}\text { level } \\
\text { (mg/ } \\
\mathrm{dL})\end{array}$ & $\begin{array}{l}\mathrm{n}, \\
\text { (n\%) }\end{array}$ & $\begin{array}{l}\text { level } \\
\text { (mg/ } \\
\mathrm{dL})\end{array}$ & $\begin{array}{l}n, \\
(n \%)\end{array}$ & $\begin{array}{l}\text { level } \\
\text { (mg/ } \\
\mathrm{dL})\end{array}$ & $\begin{array}{l}\mathrm{n}, \\
(\mathrm{n} \%)\end{array}$ & $\begin{array}{l}\text { level } \\
\text { (mg/ } \\
\mathrm{dL})\end{array}$ & $\begin{array}{l}\mathrm{n}, \\
(\mathrm{n} \%)\end{array}$ & $\begin{array}{l}\text { level } \\
\text { (mg/ } \\
\mathrm{dL})\end{array}$ & \\
\hline dyslipidemia & $\begin{array}{l}1010 \\
(45.5)\end{array}$ & $\begin{array}{l}440 \\
(42.1) \\
a\end{array}$ & / & $\begin{array}{l}412 \\
(49.8) \\
b\end{array}$ & / & $\begin{array}{l}59 \\
(52.2) \\
b\end{array}$ & / & $\begin{array}{l}56 \\
(40.6) \\
a\end{array}$ & / & $\begin{array}{l}19 \\
(48.7) \\
a b\end{array}$ & / & $\begin{array}{l}15 \\
(41.7) \\
a\end{array}$ & / & $\begin{array}{l}9 \\
(45.0) \\
\mathrm{ab}\end{array}$ & / & 0.024 \\
\hline high TC & $\begin{array}{l}341 \\
(15.4)\end{array}$ & $\begin{array}{l}149 \\
(14.3) \\
a\end{array}$ & $\begin{array}{l}279.3 \pm \\
25.8\end{array}$ & $\begin{array}{l}113 \\
(13.6) \\
a\end{array}$ & $\begin{array}{l}285.3 \pm \\
35.0\end{array}$ & $\begin{array}{l}34 \\
(30.1) \\
b\end{array}$ & $\begin{array}{l}271.5 \pm \\
24.9\end{array}$ & $\begin{array}{l}31 \\
(22.5) \\
b, c\end{array}$ & $\begin{array}{l}265.3 \pm \\
9.6\end{array}$ & $\begin{array}{l}7 \\
(17.9) \\
\text { abc }\end{array}$ & $\begin{array}{l}280.9 \pm \\
30.2\end{array}$ & $\begin{array}{l}4 \\
(11.1) \\
a\end{array}$ & $\begin{array}{l}276.5 \pm \\
39.1\end{array}$ & $\begin{array}{l}3 \\
(15.0) \\
a b c\end{array}$ & $\begin{array}{l}267.2 \pm \\
32.3\end{array}$ & $\begin{array}{l}< \\
0.001\end{array}$ \\
\hline high TG & $\begin{array}{l}636 \\
(28.7)\end{array}$ & $\begin{array}{l}249 \\
(23.9) \\
a\end{array}$ & $\begin{array}{l}297.2 \pm \\
103.5\end{array}$ & $\begin{array}{l}264 \\
(31.9) \\
b\end{array}$ & $\begin{array}{l}285.5 \pm \\
79.9\end{array}$ & $\begin{array}{l}53 \\
(46.9) \\
c\end{array}$ & $\begin{array}{l}289.2 \pm \\
63.2\end{array}$ & $\begin{array}{l}44 \\
(31.9) \\
\mathrm{b}\end{array}$ & $\begin{array}{l}268.5 \pm \\
56.0\end{array}$ & $\begin{array}{l}12 \\
(30.8) \\
\mathrm{ab}\end{array}$ & $\begin{array}{l}262.6 \pm \\
33.7\end{array}$ & $\begin{array}{l}8 \\
(22.2) \\
a b\end{array}$ & $\begin{array}{l}273.1 \pm \\
58.1\end{array}$ & $\begin{array}{l}6 \\
(30.0) \\
a b\end{array}$ & $\begin{array}{l}263.5 \pm \\
64.0\end{array}$ & $\begin{array}{l}< \\
0.001\end{array}$ \\
\hline high LDL-C & $\begin{array}{l}337 \\
(15.2)\end{array}$ & $\begin{array}{l}142 \\
(13.6) \\
a\end{array}$ & $\begin{array}{l}184.1 \pm \\
29.5\end{array}$ & $\begin{array}{l}128 \\
(15.5) \\
a\end{array}$ & $\begin{array}{l}182.6 \pm \\
21.8\end{array}$ & $\begin{array}{l}35 \\
(30.1) \\
b\end{array}$ & $\begin{array}{l}179.5 \pm \\
16.2\end{array}$ & $\begin{array}{l}19 \\
(13.8) \\
\frac{a}{}\end{array}$ & $\begin{array}{l}174.4 \pm \\
20.0\end{array}$ & $\begin{array}{l}6 \\
(15.4) \\
a b\end{array}$ & $\begin{array}{l}174.4 \pm \\
19.5\end{array}$ & $\begin{array}{l}5 \\
(13.9) \\
a\end{array}$ & $\begin{array}{l}176.5 \pm \\
12.2\end{array}$ & $\begin{array}{l}2 \\
(10.0) \\
a b\end{array}$ & $\begin{array}{l}209.5 \pm \\
26.0\end{array}$ & $\begin{array}{l}< \\
0.001\end{array}$ \\
\hline low HDL-C & $\begin{array}{l}512 \\
(23.1)\end{array}$ & $\begin{array}{l}248 \\
(23.8)\end{array}$ & $\begin{array}{l}31.7 \pm \\
5.2\end{array}$ & $\begin{array}{l}179 \\
(21.6)\end{array}$ & $\begin{array}{l}31.9 \pm \\
4.4\end{array}$ & $\begin{array}{l}33 \\
(29.2)\end{array}$ & $\begin{array}{l}30.2 \pm \\
4.1\end{array}$ & $\begin{array}{l}29 \\
(21.0)\end{array}$ & $\begin{array}{l}32.3 \pm \\
4.4\end{array}$ & $\begin{array}{l}9 \\
(23.1)\end{array}$ & $\begin{array}{l}28.1 \pm \\
3.7\end{array}$ & $\begin{array}{l}9 \\
(25.0)\end{array}$ & $\begin{array}{l}28.7 \pm \\
4.6\end{array}$ & $\begin{array}{l}5 \\
(25.0)\end{array}$ & $\begin{array}{l}32.3 \pm \\
2.6\end{array}$ & 0.663 \\
\hline
\end{tabular}

TC Total cholesterol, TG Triglycerides, LDL-C Low density lipoprotein cholesterol, HDL-C High density lipoprotein cholesterol; $\mathrm{a}, \mathrm{b}$ and $\mathrm{c}$ denote the difference of ethnic groups by $x^{2}$ test at 0.05 


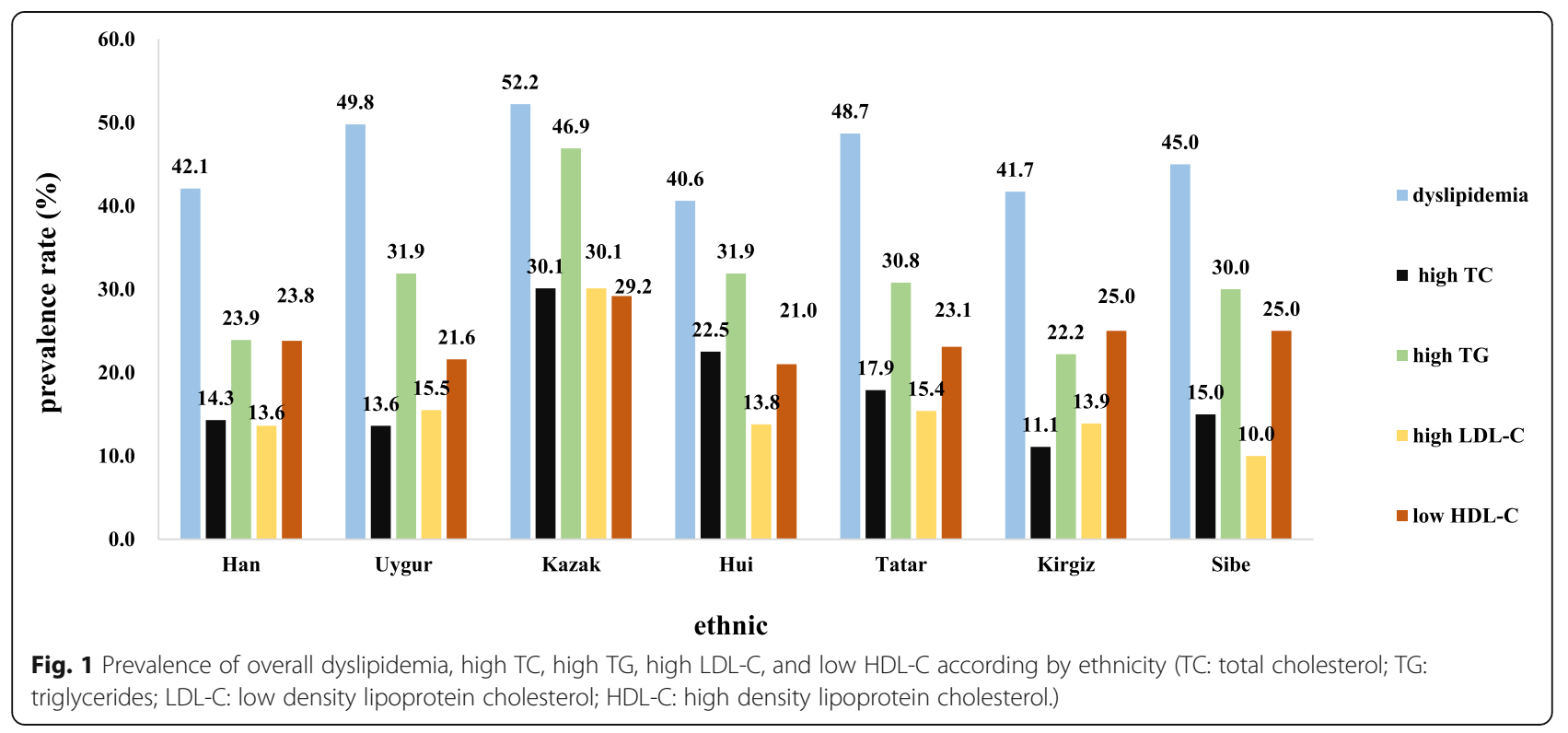

$<0.001$ ). The only significant difference between females and males in Hui patients was the prevalence of high TC: males $17.7 \%$ and females $33.3 \%(P=0.043)$. There were no significant differences in overall and isolated dyslipidemia prevalence in Kazak, Tatar, Kirgiz, and Sibe groups between females and males (all $P>0.05$ ). The gender distribution of dyslipidemia across ethnic groups is presented in Table 4.

\section{$A B C B 1$ and $S L C O 1 B 1$ distribution}

The distribution of $A B C B 1$ and SLCO1B1 genotypes and alleles across ethnic groups is displayed in Table 5. The prevalence of $A B C B 1$ C3435T genotypes in Uygur patients was significantly different among ethnicities $(P<$ $0.001)$. The occurrence of the $A B C B 1 \mathrm{C} 3435 \mathrm{~T}$ TT variant was demonstrated in $25.4 \%$ of the Uygur patients, which was significantly higher than the $16.6 \%$ of the Han group $(P<0.05)$. By contrast, the $A B C B 1$ C3435T CC variant was found in $24.5 \%$ of the Uygur group, significantly lower than the $34.4 \%$ of the Han group $(P<0.05)$. Compared with the Han group (41.1\%), the distribution of allele $\mathrm{T}$ was more prevalent in the Uygur group $(P<$ $0.05)$. The distribution frequencies of genotypes and alleles for $A B C B 1$ G2677T and SLCO1B1 T521C across ethnic groups were statistically similar $(P>0.05)$. All genotypes and allele frequencies were consistent with HWE $(P>0.05)$ except for $A B C B 1$ G2677T genotype frequencies in the Han and Uygur groups $(P<0.05)$.

\section{Lipid profiles of patients with CHD the present and other studies}

The included population groups were diverse, and all patients had CHD. The study populations varied from Japanese, Korean, American, British, Turk, and Pakistani and the same ethnic populations in different studies (Chinese Han, and Uygur). The British patients had the highest levels of LDL-C $(191.1 \pm 42.08 \mathrm{mg} / \mathrm{dL})$, whereas the Chinese Han patients in another study were the lowest $(100.1 \pm 32.5 \mathrm{mg} / \mathrm{dL})$. The British patients had the highest levels of TC and TG $(270.2 \pm 43.41 \mathrm{mg} / \mathrm{dL}$ and $214.2 \pm 114.2 \mathrm{mg} / \mathrm{dL}$, respectively). In another study, the Chinese Han patients had the lowest TC level (155.8 \pm $37.1 \mathrm{mg} / \mathrm{dL}$ ), and Japanese patients had the lowest TG level $(128.0 \pm 75.0 \mathrm{mg} / \mathrm{dL})$. The LDL-C, HDL-C, and TG levels of Uygur patients in the current study were similar to those of Uygur patients in another study; however, the TC level of Uygur patients in the current study $(196.8 \pm 40.6 \mathrm{mg} / \mathrm{dL})$ was higher than that of Uygur patients in another study $(169.7 \pm 51.0 \mathrm{mg} / \mathrm{dL})$. In addition, The LDL-C and HDL-C levels of Chinese Han patients in the current study were similar to those of Uygur patients in another study; however, the TC and TG levels of Chinese Han patients in the current study were higher than those of Han patients in the other study. These findings suggest that the lipid levels of patients with CHD differ across ethnicities or regions. The lipid profile of patients with CHD in the current study and other studies is summarized in Table 6.

\section{Allele frequency of $A B C B 1$ and $S \angle C O 1 B 1$ compared with other studies}

The current study compares $A B C B 1$ C3435T and $A B C B 1 \mathrm{G} 2677 \mathrm{~T}$ allele frequencies in Uygur and Chinese Han patients and various ethnic groups of Japanese, Greek, Dutch, and Australian patients with CHD displayed in Table 7. The $\mathrm{T}$ allele frequency of $A B C B 1$ C3435T in Uygur patients in the current study was significantly lower than that of Australian patients $(P<$ 


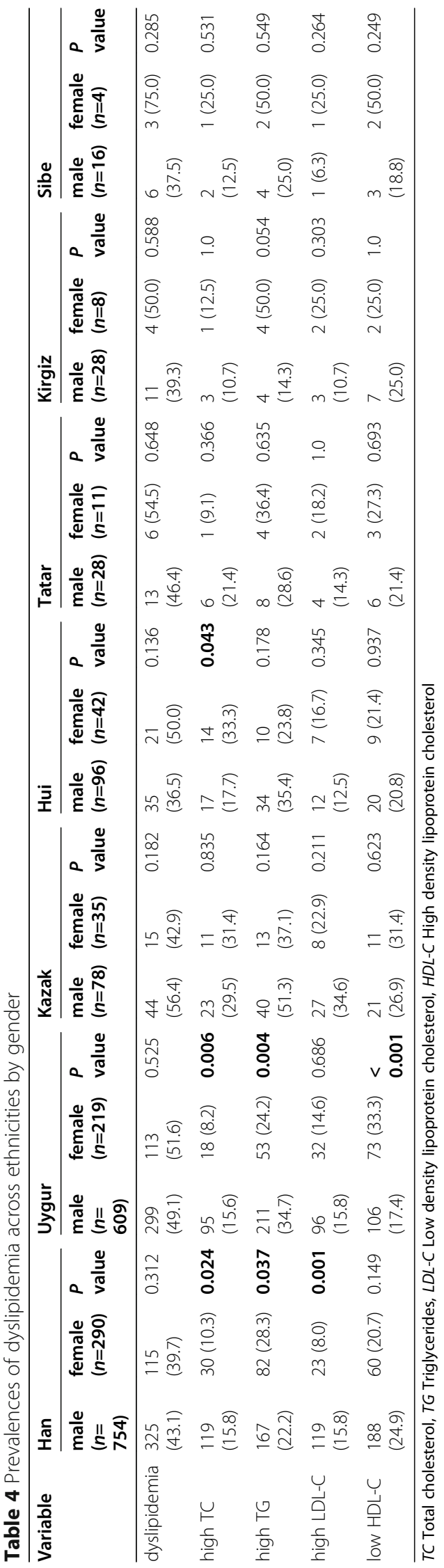


Table 5 Polymorphisms of ABCB1 and SLCO1B1 across ethnicities

\begin{tabular}{|c|c|c|c|c|c|c|c|c|c|}
\hline Polymorphisms, n (\%) & $\begin{array}{l}\text { Overall } \\
(n=2218)\end{array}$ & $\begin{array}{l}\text { Han } \\
(n=1044)\end{array}$ & $\begin{array}{l}\text { Uygur } \\
(n=828)\end{array}$ & $\begin{array}{l}\text { Kazak } \\
(n=113)\end{array}$ & $\begin{array}{l}\text { Hui } \\
(n=138)\end{array}$ & $\begin{array}{l}\text { Tatar } \\
(n=39)\end{array}$ & $\begin{array}{l}\text { Kirgiz } \\
(n=36)\end{array}$ & $\begin{array}{l}\text { Sibe } \\
(n=20)\end{array}$ & $P$ value \\
\hline \multicolumn{10}{|l|}{$A B C B 1$ C3435T } \\
\hline CC & $671(30.3)$ & $359(34.4)^{a}$ & $203(24.5)^{b}$ & $33(29.2)^{a b}$ & $42(30.4)^{a b}$ & $16(41.0)^{a b}$ & $11(30.6)^{a b}$ & $7(35.0)^{a b}$ & \multirow[t]{3}{*}{$<.001$} \\
\hline $\mathrm{CT}$ & $1103(49.7)$ & $512(49.0)$ & $415(50.1)$ & $57(50.4)$ & $75(54.3)$ & $16(41.0)$ & $17(47.2)$ & $11(55.0)$ & \\
\hline$\pi$ & $444(20.0)$ & $173(16.6)^{a}$ & $210(25.4)^{b}$ & $23(20.4)^{a b}$ & $21(15.2)^{a b}$ & $7(18.0)^{a b}$ & $8(22.2)^{a b}$ & $2(10.0)^{a b}$ & \\
\hline C allele & $2445(55.1)$ & $1230(58.9)^{\mathrm{a}}$ & $821(49.6)^{b}$ & $123(54.4)^{a b}$ & $159(57.6)^{a b}$ & $48(61.5)^{a b}$ & $39(54.2)^{a b}$ & $25(62.5)^{a b}$ & \multirow[t]{2}{*}{$<.001$} \\
\hline T allele & $1991(44.9)$ & $858(41.1)^{\mathrm{a}}$ & $835(50.4)^{b}$ & $103(45.6)^{a b}$ & $117(42.4)^{a b}$ & $30(38.5)^{a b}$ & $33(45.8)^{a b}$ & $15(37.5)^{a b}$ & \\
\hline \multicolumn{10}{|l|}{$A B C B 1 \mathrm{G} 2677 \mathrm{~T}$} \\
\hline GG & $606(27.3)$ & $297(28.4)$ & $210(25.4)$ & 36 (31.9) & $36(26.1)$ & $12(30.8)$ & $8(22.2)$ & $7(35.0)$ & \multirow[t]{3}{*}{0.586} \\
\hline GT & $956(43.1)$ & $429(41.1)$ & $365(44.1)$ & $51(45.1)$ & $68(49.3)$ & $17(43.6)$ & $17(47.2)$ & $9(45.0)$ & \\
\hline$\pi$ & $656(29.6)$ & $318(30.5)$ & $253(30.6)$ & $26(23.0)$ & $34(24.6)$ & $10(25.6)$ & $11(30.6)$ & $4(20.0)$ & \\
\hline G allele & $2168(48.9)$ & $1023(49.0)$ & 785 (47.4) & $123(54.4)$ & $140(50.7)$ & $41(52.6)$ & $33(45.8)$ & $23(57.5)$ & \multirow[t]{2}{*}{0.37} \\
\hline T allele & $2268(51.1)$ & 1065 (51.0) & 871 (52.6) & $103(45.6)$ & $136(49.3)$ & $37(47.4)$ & $39(54.2)$ & $17(42.5)$ & \\
\hline \multicolumn{10}{|l|}{ SLCO1B1 T521C } \\
\hline$\Pi$ & 1737 (78.3) & $813(77.9)$ & 655 (79.1) & 87 (77.0) & $111(80.4)$ & $29(74.4)$ & $27(75.0)$ & $15(75.0)$ & \multirow[t]{3}{*}{0.326} \\
\hline$C T$ & $450(20.3)$ & $219(21.0)$ & 161 (19.4) & $22(19.5)$ & 27 (19.6) & $9(23.1)$ & $7(19.4)$ & $5(25.0)$ & \\
\hline $\mathrm{CC}$ & $31(1.4)$ & $12(1.1)$ & $12(1.4)$ & $4(3.5)$ & $0(0)$ & $1(2.6)$ & $2(5.6)$ & $0(0)$ & \\
\hline T allele & 3924 (88.5) & 1845 (88.4) & 1471 (88.8) & $196(86.7)$ & $249(90.2)$ & 67 (85.9) & $61(84.7)$ & 35 (87.5) & \multirow[t]{2}{*}{0.717} \\
\hline C allele & $512(11.5)$ & 243 (11.6) & $185(11.2)$ & 30 (13.3) & $27(9.8)$ & $11(14.1)$ & $11(15.3)$ & $5(12.5)$ & \\
\hline
\end{tabular}

$\mathrm{a}$ and $\mathrm{b}$ denote the difference of ethnic groups by $\mathrm{x}^{2}$ test at 0.05

0.05) but higher than Chinese Han published in another study. The $\mathrm{T}$ allele frequency of $A B C B 1 \mathrm{C} 3435 \mathrm{~T}$ in the Uygur patients in the current study was not significantly different from Uygur patients described in another study $(P>0.05)$. The current study's $\mathrm{T}$ allele frequencies of $A B C B 1$ G2677T in Uygur and Chinese Han patients were significantly higher than that of Greek patients $(P<$ 0.05). Comparision of the SLCO1B1 T521C allele frequencies in Uygur and Chinese Han patients of the current study and Japanese, Macedonian, Thai, and English patients with CHD from other studies are displayed in Table 8. The current study's $\mathrm{C}$ allele frequency of

Table 6 Lipid profiles of patients with CHD in this and other studies

\begin{tabular}{|c|c|c|c|c|c|}
\hline Population & LDL-C (mg/dL) & HDL-C (mg/dL) & $\mathrm{TC}(\mathrm{mg} / \mathrm{dL})$ & TG (mg/dL) & References \\
\hline Chinese Han & $114.8 \pm 38.3$ & $36.7 \pm 9.7$ & $193.7 \pm 52.2$ & $175.4 \pm 120.5$ & current study \\
\hline Chinese Han & $100.1 \pm 32.5$ & $42.5 \pm 10.4$ & $155.8 \pm 37.1$ & $137.3 \pm 79.7$ & [10] \\
\hline Uygur & $116.8 \pm 34.4$ & $33.6 \pm 8.5$ & $196.8 \pm 40.6$ & $176.3 \pm 100.1$ & current study \\
\hline Uygur & $113.7 \pm 41.4$ & $34.8 \pm 12.8$ & $169.7 \pm 51.0$ & $172.8 \pm 95.7$ & [11] \\
\hline Kazak & $122.9 \pm 35.6$ & $35.2 \pm 8.5$ & $199.9 \pm 38.7$ & $179.0 \pm 125.8$ & current study \\
\hline Hui & $116.0 \pm 38.7$ & $35.2 \pm 8.9$ & $191.0 \pm 44.5$ & $165.7 \pm 72.7$ & \\
\hline Tatar & $113.3 \pm 35.6$ & $34.8 \pm 11.2$ & $196.0 \pm 41.8$ & $171.9 \pm 41.6$ & \\
\hline Kirgiz & $105.2 \pm 32.1$ & $36.7 \pm 11.2$ & $193.7 \pm 47.9$ & $163.0 \pm 73.5$ & \\
\hline Sibe & $102.1 \pm 28.6$ & $37.1 \pm 8.5$ & $189.4 \pm 41.4$ & $165.7 \pm 86.8$ & \\
\hline Japanese & $123.0 \pm 24.0$ & $47.0 \pm 12.0$ & $196.0 \pm 31.0$ & $128.0 \pm 75.0$ & [12] \\
\hline Korean & $110.0 \pm 31.0$ & $40.0 \pm 13.0$ & $183.0 \pm 36.0$ & $165.0 \pm 93.0$ & [13] \\
\hline American & $150.2 \pm 25.9$ & $42.9 \pm 11.4$ & $232.6 \pm 34.1$ & $197.7 \pm 105.6$ & [14] \\
\hline British & $191.1 \pm 42.08$ & $44.57 \pm 13.18$ & $270.2 \pm 43.41$ & $214.2 \pm 114.2$ & [15] \\
\hline Turk & $120.08 \pm 27.67$ & $36.33 \pm 9.76$ & $181.64 \pm 35.42$ & / & [16] \\
\hline Pakistani & $104.6 \pm 37.94$ & $45.1 \pm 11.63$ & $208.2 \pm 54.11$ & $214.5 \pm 74.60$ & [17] \\
\hline
\end{tabular}

TC Total cholesterol, TG Triglycerides, LDL-C Low density lipoprotein cholesterol, HDL-C High density lipoprotein cholesterol 
Table $7 A B C B 1$ allele frequencies in Uygur and Chinese Han populations with CHD in comparison with other study populations

\begin{tabular}{|c|c|c|c|c|c|c|}
\hline \multirow[t]{2}{*}{ Ethnic } & \multirow[t]{2}{*}{$\mathbf{n}$} & \multicolumn{2}{|c|}{$A B C B 1$ C3435T, n (\%) } & \multicolumn{2}{|c|}{$A B C B 1 \mathrm{G} 2677 \mathrm{~T}, \mathrm{n}(\%)$} & \multirow[t]{2}{*}{ References } \\
\hline & & $C$ & $\mathbf{T}$ & G & $T$ & \\
\hline Uygur & 828 & $821(49.6)$ & $835(50.4)^{a b}$ & $785(47.4)$ & $871(52.6)^{a b}$ & current study \\
\hline Uygur & 527 & $486(46.1)$ & $568(53.9)^{b}$ & / & / & [18] \\
\hline Chinese Han & 2445 & $1230(58.9)$ & $858(41.1)^{c}$ & $1023(49.0)$ & $1065(51.0)^{a b}$ & current study \\
\hline Chinese Han & 162 & $180(55.6)$ & $144(44.4)^{c d}$ & $147(45.4)$ & $177(54.6)^{b}$ & [19] \\
\hline Japanese & 27 & $32(59.3)$ & $22(40.7)^{a b c d}$ & $24(44.4)$ & $30(55.6)^{a b}$ & [20] \\
\hline Greek & 169 & $185(54.7)$ & $153(45.3)^{\text {acd }}$ & $221(65.4)$ & $117(34.6)^{c}$ & [21] \\
\hline Netherlanderen & 82 & $76(46.3)$ & $88(53.7)$ abde & $90(54.9)$ & $74(45.1)^{\mathrm{a}}$ & [22] \\
\hline Australian & 117 & $86(36.8)$ & $148(63.2)^{e}$ & / & / & {$[7]$} \\
\hline
\end{tabular}

$a, b, c, d$, and e denote the difference of ethnic groups by $x^{2}$ test at 0.05

SLCO1B1 T521C in Uygur and Chinese Han patients was significantly lower than that of English patients $(P<$ $0.05)$.

\section{Discussion}

The Uygur population accounts for most of the population in Xinjiang; by contrast, there are only 5156 Tatar people in China, making it the least populous ethnic group in China. Only 36 Kirgiz and 36 Tatar patients were recruited in this study; therefore, deviations may occur that might not reflect these two groups' characteristics. In Asian populations, obesity is defined as BMI > $26 \mathrm{~kg} / \mathrm{m}^{2}$ [26]. The average BMI of Uygur, Kazak, and Tatar patients all exceeded the normal level. The prevalence of hypertension and diabetes mellitus in the seven ethnic groups were all more than $50 \%$ and $20 \%$, respectively.

Lipids have many functions, from constituting membrane components to cell signaling, and are associated with several chronic diseases [27-31]. The prevalence of dyslipidemia in adults in China is $34.7 \%$ [32]; it is a strong factor predisposing patients to obesity and CHD [5]. Elevated levels of TG also appear to be an independent risk factor for CHD [17, 33]. The prevalence of dyslipidemia differed significantly among ethnicities $(P=$

Table 8 SLCO1B1 T521C allele frequencies in Uygur and Chinese Han populations with CHD in comparison with other study populations

\begin{tabular}{lllll}
\hline Ethnic & $\mathbf{n}$ & \multicolumn{2}{l}{ SLCO1B1 T521C } & References \\
\cline { 3 - 4 } & & $\mathbf{T}$ & $\mathbf{C}$ & \\
\hline Uygur & 193 & $1471(88.8)$ & $185(11.2)^{a}$ & current study \\
Chinese Han & 403 & $1845(88.5)$ & $243(11.6)^{a}$ & current study \\
Japanese & 27 & $46(85.2)$ & $8(14.8)^{a b}$ & {$[20]$} \\
Macedonian & 156 & $268(85.9)$ & $44(14.1)^{a}$ & {$[23]$} \\
Thai & 391 & $690(88.2)$ & $92(11.8)^{a}$ & {$[24]$} \\
English & 429 & $631(73.5)$ & $227(26.5)^{b}$ & {$[25]$}
\end{tabular}

$a$ and $b$ denote the difference of ethnic groups by $x^{2}$ test at 0.05
0.024); the prevalence in Uygur and Kazak groups was significantly higher than in Han, Hui, and Kirgiz groups. High-fat and high-sugar diets and lifestyles are associated with these communities, especially the Uygur, Kazak, and Tatar populations. The prevalences of dyslipidemia in Uygur, Kazak, and Han CHD patients were $49.8 \%, 52.2 \%$, and $42.1 \%$, respectively, were much higher than values reported in an epidemiological investigation of these ethnic groups in Xinjiang (42.4\%, $31.6 \%$, and $30.2 \%$, respectively) [34].

According to global dyslipidemia guidelines, LDL-C is the primary therapeutic target of both primary and secondary prevention [35]. The average prevalence of high LDL-C in enrolled patients was $15.2 \%$, much higher than that of Chinese adults (8.1\%) [36]. The prevalences of high LDL-C of Uygur, Kazak, and Han CHD patients were $15.5 \%, 30.1 \%$, and $13.6 \%$, respectively, which were much higher than the value reported in a previous report from Xinjiang $(2.4 \%, 2.9 \%$, and $2.0 \%$, respectively) [34]. The Sibe CHD group had the lowest prevalence of high LDL-C (10.0\%), much higher than that in Chinese adults. Ballantyne et al. reported that low HDL-C and high TG co-occurrence were potent risks for $\mathrm{CHD}$ [37]. Although there was no significant difference in low HDL-C across ethnic groups in the current study $(P=$ $0.663)$, the average prevalence of low HDL-C in overall patients $(23.1 \%)$ was higher than that of Chinese adults (20.4\%) [36]. The average prevalence of high TG in overall patients $(28.7 \%)$ was higher than that of Chinese adults (13.8\%) [36]. It is estimated that $56 \%$ of the total heart diseases may be due to high $\mathrm{TC}(>200 \mathrm{mg} / \mathrm{dL})$ alone [38]. The average prevalences of high TC (15.4\%) and TC level $(195.6 \pm 53.0 \mathrm{mg} / \mathrm{dL})$ in overall patients were much higher than those of Chinese adults $(6.9 \%$ and $181.7 \pm 39.0 \mathrm{mg} / \mathrm{dL}$, respectively). The prevalences of high TC, high TG, and high LDL-C in the Kazak group were highest among all studied ethnic groups. In the Kirgiz group, the prevalences of high TC and high TG were the lowest. 
sdLDL-C is a surrogate biomarker strongly associated with cardiovascular disease. It also contributes to the pathophysiology of several diseases. The mean sdLDL level differed significantly among ethnicities $(P=0.04)$; sdLDL-c should be considered in clinical practice to improve the management of cardiovascular disease and risk factors for progression [39]. ApoE is a multifunctional protein involved in lipid metabolism and neurodegenerative diseases. It is a subclass of HDL whose major function is to mediate the binding of lipoproteins or lipid complexes in serum and interstitial fluids to specific cell-surface receptors.

ApoB is a diagnostic index of the risk of vascular disease and a therapeutic target for statin therapy [40]. Mean ApoB and ApoE levels differed significantly among ethnicities. Mean ApoA1 levels were significantly higher in Han, Tatar, and Sibe groups than other ethnic groups except for the Kazak group $(P=0.027)$. The prognostic value of ApoA1 self-antibodies in cardiovascular diseases should be highlighted [41]. Lipoprotein(a) $[\mathrm{Lp}(\mathrm{a})]$ is an established cardiovascular risk factor, acting by either accelerating atherosclerosis progression or inducing a prothrombotic/antifibrinolytic systemic milieu $[42,43]$. In addition, it has been suggested that elevated Lp(a) may significantly contribute to residual cardiovascular risk in patients with coronary artery disease and optimal LDL-C level [44]. The impact of $L p(a)$ has gained more and more interest in the last decade in the setting of dyslipidemia, and it is an essential test for CHD patients. There were only part of enrolled patients with $\operatorname{Lp}(\mathrm{a})$ test in this retrospective study; therefore, the Lp(a) level could not included into the analysis.

In the current study, the proportion of males suffering from CHD was higher than females $(72.5 \%$ vs. $27.5 \%)$. There were no significant differences in the overall prevalence of dyslipidemia across ethnic groups between males and females. By contrast, the prevalences of high LDL-C, high TG, high TC, and low HDL-C differed significantly by gender in Han, Uygur, and Hui patients.

The U.S. Preventive Services Task Force suggested that lifestyle modifications are unlikely to reduce lipid levels substantially and that many patients with hyperlipidemia require medications to reach therapeutic goals [45]. A secondary prevention strategy was applied to patients with clinically diagnosed CHD, and high-intensity statin therapy was recommended. Applying genetic information to individualize drug treatments to maximize efficacy and avoid adverse events, or pharmacogenetics, is an essential component of precision medicine. Individual genotypes are now understood to influence drug disposition and activity [46].

The SLCO1B1 T521C variant is associated with reduced activity of the hepatic organic anion transporter polypeptide 1B1 transporter and increased plasma concentrations of statin. Polymorphisms in SLCO1B1 are implicated in milder forms of statin intolerance [47]. P-gp is an efflux transporter that is the product of the multidrug resistance $A B C B 1$ gene located on the cell's apical membrane. It limits drug absorption from the gastrointestinal tract and promotes the efflux of the compounds into the bile and urine [48]. This study screened genetic variability of three candidate genes associated with statin's membrane transport and hepatic metabolism that may affect safety and efficacy and compared $A B C B 1$ C3435T, ABCB1 G2677T, and SLCO1B1 T521C polymorphisms in the seven ethnic groups. The prevalence of Uygur $A B C B 1$ C3435T genotypes differed significantly among ethnicities $(P<0.001)$. The occurrence of the $A B C B 1 \mathrm{C} 3435 \mathrm{~T}$ TT variant was demonstrated in $25.4 \%$ of the Uygur patients, which was significantly higher than the $16.6 \%$ of the Han group $(P<0.05)$. Compared with Han groups $(41.1 \%)$, the distribution of allele $\mathrm{T}$ was more prevalent in the Uygur group $(P<0.05)$. A previous study reported that Chinese Han patients with the $A B C B 1$ 2677GG or 3435TT genotypes showed significantly lower lipid profiles and higher alanine transaminase levels [49]. de Keyser et al. reported a significant association between the SLCO1B1 polymorphism and the risk of the adverse drug reactions in atorvastatin users with a starting dose of more than $20 \mathrm{mg}$ atorvastatin and with at least one minor allele [50]. Although a contrary conclusion was reported in another study [51], the distribution frequencies of genotype and allele toward $A B C B 1$ G2677T and SLCO1B1 T521C across the seven ethnic groups were statistically similar $(P>$ 0.05). The current study compared the allele frequency of $A B C B 1$ and SLCO1B1 to those of other studies, and found that lipid levels and gene polymorphisms in populations with CHD differed across ethnic groups and regions.

\section{Strengths and limitations}

There were several strengths in this study. First, seven ethnic groups in Xinjiang province were studied; this is the first study to analyze the distribution of SLCO1B1*5 and ABCB1 G2677T gene polymorphisms in these ethnic groups. Second, there are few reports of lipid profiles in Sibe, Tatar, and Kirgiz populations; therefore, the current study can provide information about minority groups with CHD. Finally, although it is well known that dyslipidemia is an essential factor of CHD, the factors affecting lipids levels are worthy of investigation. Ethnicity, gender, and lifestyle were all factors that affected lipids levels in Xinjiang populations. The small sample size limited the study in Tatar, Kirgiz, and Sibe groups. 


\section{Conclusion}

There are significantly different prevalences of dyslipidemia, high TC, high TG, and high LDL-C in Han, Uygur, Kazak, Hui, Tatar, Kirgiz, and Sibe CHD patients in Xinjiang. Ethnicity, gender, and lifestyle were crucial factors that affected lipid levels. The prevalence of the $A B C B 1$ C3435T polymorphism differed significantly across ethnicities. The study provides new data regarding the epidemiology of lipid profiles and gene polymorphisms and provides a basis for selecting precise lipidlowering agents to prevent and treat $\mathrm{CHD}$ according to across ethnicities of Xinjiang.

\begin{abstract}
Abbreviations
CHD: Coronary heart disease; TC: Total cholesterol; TG: Triglycerides; LDLC: Low density lipoprotein cholesterol; HDL-C: High density lipoprotein cholesterol; ABCB1: ATP-binding cassette transporter B1; P-gp: P-glycoprotein; SLCO1B1: Solute carrier organic anion transporter 1B1; sdLDL: Small dense low density lipoprotein; ApoA1: Apolipoprotein A1; ApoB: Apolipoprotein B100; ApoE: Apolipoproteins E; BMI: Body mass index; HWE: Hardy-Weinberg equilibrium; Lp(a): Lipoprotein(a); PHOXUAR: People's Hospital of Xinjiang Uygur Autonomous Region
\end{abstract}

\section{Supplementary Information}

The online version contains supplementary material available at https://doi. org/10.1186/s12944-021-01544-3.

\section{Additional file 1.}

\section{Acknowledgments}

The authors would like to thank the Science and Technology Department of Xinjiang Uygur Autonomous Region and Department of Tianshan District for financially supported.

\section{Authors' contributions}

Data curation: Luhai Yu and Li Xu. Formal analysis: Ting Zhao and Jie Feng. Sample collection: Tingting Wang and Li Sun. Study designed: Jianhua Wu and Hongjian Li. Validation: Hongjian Li. Writing \& Review: Tingting Wang and Li Sun. Technical support provided: Li Xu and Jie Feng. The author(s) read and approved the final manuscript.

\section{Funding}

The authors disclosed receipt of the following financial support for the research and/or publication of this article: This work was supported by 1 . General program of Natural Science Foundation of Xinjiang Uygur Autonomous Region, Project No. 2018D01C108; 2. Tianshan District Science and Technology Foundation of Urumuqi, Xinjiang, Project No. T2017-07.

\section{Availability of data and materials}

All datasets about this study available from the corresponding author.

\section{Declarations}

\section{Ethics approval and consent to participate}

The purpose and experimental procedures of the study were explained to all patients and legally authorized representative of one deceased patient, who gave informed written consent prior to the study. All patients or their authorized representative explicitly provided permission for genotyping as well as for collection of relevant clinical data. The study was conducted according to the standards of the Declaration of Helsinki and was approved by ethics committee of PHXUAR (approval number: 2017095).

\section{Consent for publication}

Not applicable

\section{Competing interests}

The authors declare that they have no competing interests.

\section{Author details}

${ }^{1}$ Department of Pharmacy, People's Hospital of Xinjiang Uygur Autonomous Region, No. 91 Tianchi Road, Tianshan District, Urumqi 830001, Xinjiang,

China. ${ }^{2}$ Institute of Clinical Pharmacy, People's Hospital of Xinjiang Uygur Autonomous Region, No. 91 Tianchi Road, Tianshan District, Urumqi 830001, Xinjiang, China. ${ }^{3}$ Internal Medicine-Cardiovascular Department, People's Hospital of Xinjiang Uygur Autonomous Region, No. 91 Tianchi Road, Tianshan District, Urumqi 830001, Xinjiang, China.

Received: 28 June 2021 Accepted: 6 September 2021 Published online: 25 September 2021

References

1. National Cholesterol Education Program (NCEP) Expert Panel on Detection. Evaluation, and Treatment of High Blood Cholesterol in Adults (Adult Treatment Panel III): Third Report of the National Cholesterol Education Program (NCEP) Expert Panel on Detection, Evaluation, and Treatment of High Blood Cholesterol in Adults (Adult Treatment Panel III) final report. Circulation. 2002;106:3143-421.

2. Sarwar N, Danesh J, Eiriksdottir G, Sigurdsson G, Wareham N, Bingham S, et al. Triglycerides and the risk of coronary heart disease: 10,158 incident cases among 262,525 participants in 29 Western prospective studies. Circulation. 2007;115:450-8.

3. Brunner FJ, Waldeyer, Ojeda, Salomaa, Kee F, Sans S, et al. Application of non-HDL cholesterol for population-based cardiovascular risk stratification: results from the Multinational Cardiovascular Risk Consortium. Lancet. 2019; 394(10215):2173-83.

4. Maitusong B, Xie X, Ma YT, Fu ZY, Yang YN, Li XM, et al. Association between ErbB3 genetic polymorphismsand coronary artery disease in the Han and Uyghur populations of China. Int J Clin Exp Med. 2015;8(9):165207.

5. Kopin L, Lowenstein C. Dyslipidemia. Ann Intern Med. 2017;167(11):ITC8196.

6. Tsimikas S, Gordts PLSM, Nora C, Yeang C, Witztum JL. Witztum: Statin therapy increases lipoprotein(a) levels. Eur Heart J. 2019;0:1-10.

7. Hoenig MR, Walker PJ, Gurnsey C, Beadle K, Johnson L. The C3435T polymorphism in $A B C B 1$ influences atorvastatin efficacy and muscle symptoms in a high-risk vascular cohort. J Clin Lipidol. 2011;5(2):91-6.

8. Niemi M, Pasanen MK, Neuvonen PJ. Organic anion transporting polypeptide 1B1: a genetically polymorphic transporter of major importance for hepatic drug uptake. Pharmacol Rev. 2011;63:157-81.

9. Josephine HL, Scott VJ, Susanne BH, Lori AO, William EK, Geoffrey SG, et al. Genetically Guided Statin Therapy on Statin Perceptions, Adherence, and Cholesterol Lowering: A Pilot Implementation Study in Primary Care Patients. J Pers Med. 2014;4(2):147-62.

10. Qian P, Cao XC, Xu XJ, Duan MQ, Zhang Q, Huang G, et al. Contribution of CYP24A1 variants in coronary heart disease among the Chinese population. Lipids Health Dis. 2020;19:181.

11. Wang YT, Buamina M, Ma YT, Fu ZY, Yang YN, Ma X, et al. Acyl-CoA: cholesterol acyltransferases-2 gene polymorphism is associated with increased susceptibility to coronary artery disease in Uygur population in Xinjiang, China. Biosci Rep. 2019;39(2):BSR20182129.

12. Nozue T, Hattori H, Ishihara M, Iwasaki T, Hirano T, Kawashiri MA, et al. Comparison of effects of pitavastatin versus pravastatin on serum proprotein convertase subtilisin/kexin type 9 levels in statin-naive patients with coronary artery disease. Am J Cardiol. 2013;111(10):1415-9.

13. Lee CW, Kang SJ, Ahn JM, Song HG, Lee JY, Kim WJ, et al. Comparison of effects of atorvastatin (20 mg) versus rosuvastatin $(10 \mathrm{mg}$ ) therapy on mild coronary atherosclerotic plaques (from the ARTMAP Trial). Am J Cardiol. 2012;109(12):1700-4

14. Nissen SE, Tuzcu EM, Schoenhagen P, Brown BG, Ganz P, Vogel RA, et al. Effect of intensive compared with moderate lipid-lowering therapy on progression of coronary atherosclerosis: a randomized controlled trial. JAMA. 2004;291(9):1071-80.

15. Mitropoulos KA, Armitage JM, Collins R, Meade TW, Reeves BE, Wallendszus KR, et al. Randomized placebo-controlled study of the effects of simvastatin on haemostatic variables, lipoproteins and free fatty acids. The Oxford Cholesterol Study Group. Eur Heart J. 1997;18(2):235-41. 
16. Tunçez A, Altunkeser BB, Öztürk B, Ateş MS, Tezcan H, Aydoğan C, et al. Comparative effects of atorvastatin $80 \mathrm{mg}$ and rosuvastatin $40 \mathrm{mg}$ on the levels of serum endocan, chemerin, and galectin-3 in patients with acute myocardial infarction. Anatol J Cardiol. 2019:22(5):240-9.

17. Shabana SSU, Sarwar S. The abnormal lipid profile in obesity and coronary heart disease (CHD) in Pakistani subjects. Lipids Health Dis. 2020;19:73.

18. Wang TT, Zhao T, Bao SC, Jia L, Feng J, Yu AP, et al. CYP2C19, PON1, and ABCB1gene polymorphisms in Han and Uygur populations with coronary artery disease in Northwestern Xinjiang, China, From 2014 Through 2019. Medicine (Baltimore). 2020;99(29):e20

19. Qu KK, Zhang CN, Dong LX, Wang SS, Zhang ZD, Zhang L. Association of $A B C B 1$ polymorphisms with lipid homeostasis and liver injury response to atorvastatin in Chinese population. Can J Physiol Pharmacol. 2020;98(1):15-22.

20. Tsamandouras N, Guo YY, Wendling T, Hall S, Galetin A, Aarons L. Modelling of atorvastatin pharmacokinetics and the identification of the effect of a BCRP polymorphism in the Japanese population. Pharmacogenet Genomics. 2017;27(1):27-38.

21. Gbandi E, Goulas A, Sevastianos V, Hadziyannis S, Panderi A, Koskinas J, et al. Common ABCB1 polymorphisms in Greek patients with chronic hepatitis C infection: A comparison with hyperlipidemic patients and the general population. Pharmacol Rep. 2016;68(2):476-82.

22. Becker ML, Visser LE, van Schaik RH, Hofman A, Uitterlinden AG, Stricker BH. Common genetic variation in the ABCB1 gene is associated with the cholesterol-lowering effect of simvastatin in males. Pharmacogenomics. 2009;10(11):1743-51

23. Mladenovska K, Grapci AD, Vavlukis M, Kapedanovska A, Eftimov A, Geshkovska NM, et al. Influence of SLCO1B1 polymorphisms on atorvastatin efficacy and safety in Macedonian subjects. Pharmazie. 2017;72(5):288-95.

24. Kaewboonlert N, Thitisopee W, Sirintronsopon W, Porntadavity S, Jeenduang N. Lack of association between SLCO1B1 polymorphisms and lipidlowering response to simvastatin therapy in Thai hypercholesterolaemic patients. J Clin Pharm Ther. 2018;43(5):647-55.

25. Voora D, Shah SH, Spasojevic I, Ali S, Reed CR, Salisbury BA, et al. The SLCO1B1*5 Genetic Variant is Associated with Statin-Induced Side Effects. J Am Coll Cardiol. 2009:54(17):1609-16.

26. Yusuf S, Hawken S, Ônpuu S, Bautista L, Franzosi MG, Commerford P, et al. Obesity and the risk of myocardial infarction in 27000 participants from 52 countries: a case-control study. Lancet. 2005;366(9497):1640-9.

27. Harshfield EL, Koulman A, Ziemek D, Marney L, Fauman EB, Paul DS, et al. An Unbiased Lipid Phenotyping Approach To Study the Genetic Determinants of Lipids and Their Association with Coronary Heart Disease Risk Factors. J Proteome Res. 2019;18(6):2397-410.

28. Griffin JL, Atherton H, Shockcor J, Atzori L. Metabolomics as a tool for cardiac research. Nat Rev Cardiol. 2011;8(11):630-43.

29. Shah SH, Kraus WE, Newgard CB. Metabolomic profiling for the identification of novel biomarkers and mechanisms related to common cardiovascular diseases: form and function. Circulation. 2012;126(9):1110-20.

30. Stegemann C, Pechlaner R, Willeit P, Langley SR, Mangino M, Mayr U, et al. Lipidomics profiling and risk of cardiovascular disease in the prospective population-based Bruneck study. Circulation. 2014;129(18):1821-31.

31. Pechlaner R, Kiechl S, Mayr M. Potential and caveats of lipidomics for cardiovascular disease. Circulation. 2016;134(21):1651-4.

32. Li SN, Zhang LF, Wang X, Chen Z, Dong Y. Status of Dyslipidemia Among Adults Aged 35 Years and Above in China. Chin Circ J. 2019;34(7):681-7.

33. Bansal S, Buring JE, Rifai N, Mora S, Sacks FM, Ridker PM. Fasting compared with nonfasting triglycerides and risk of cardiovascular events in women. JAMA. 2007;298(3):309-16.

34. Guo SX, Ma RL, Guo H, Ding YS, Liu JM, Zhang M, et al. Epidemiological analysis of dyslipidemia in adults of three ethnicities in Xinjiang, China. Genet Mol Res. 2014;13(2):2385-93.

35. Pearson GJ, Thanassoulis G, Anderson T, Barry AR, Couture P, Dayan N, et al. 2021 Canadian Cardiovascular Society Guidelines for the Management of Dyslipidemia for the Prevention of Cardiovascular Disease in the Adult. Can J Cardiol. 2021;S0828-282X(21):00165-3.

36. Zhang M, Deng Q, Wang L, Huang Z, Zhou M, Li Y, et al. Prevalence of dyslipidemia and achievement of low-density lipoprotein cholesterol targets in Chinese adults: A nationally representative survey of 163,641 adults. Int J Cardiol. 2018;260:196-203.

37. Ballantyne CM, Olsson AG, Cook TJ, Mercuri MF, Pedersen TR, Kjekshus J. Influence of low high-density lipoprotein cholesterol and elevated triglyceride on coronary heart disease events and response to simvastatin therapy in 4S. Circulation. 2001;104(25):3046-51.

38. Kwon D, Yi JJ, Ohrr H, Yi SW. Total cholesterol and mortality from ischemic heart disease and overall cardiovascular disease in Korean adults. Medicine (Baltimore). 2019;98(36):e17013.

39. Santos HO, Earnest CP, Tinsley GM, Izidoro LFM, Macedo RCO. Small dense low-density lipoprotein-cholesterol (sdLDL-C): Analysis, effects on cardiovascular endpoints and dietary strategies. Prog Cardiovasc Dis. 2020; 63(4):503-9.

40. Sniderman AD. Applying apoB to the Diagnosis and Therapy of the Atherogenic Dyslipoproteinemias: A Clinical Diagnostic Algorithm. Curr Opin Lipidol. 2004;15(4):433-8.

41. Chistiakov DA, Orekhov AN, Bobryshev Y. ApoA1 and ApoA1-specific selfantibodies in cardiovascular disease. Lab Invest. 2016;96(7):708-18.

42. Ferretti G, Bacchetti T, Johnston TP, Banach M, Pirro M, Sahebkar A Lipoprotein(a): A missing culprit in the management of athero-thrombosis? J Cell Physiol. 2018;233(4):2966-81.

43. Gragnano F, Fimiani F, Di Maio M, Cesaro A, Limongelli G, Cattano D, et al. Impact of lipoprotein(a) levels on recurrent cardiovascular events in patients with premature coronary artery disease. Intern Emerg Med. 2019;14(4):621-5.

44. Cesaro A, Schiavo A, Moscarella E, Coletta S, Conte M, Gragnano F, et al. Lipoprotein(a): a genetic marker for cardiovascular disease and target for emerging therapies. J Cardiovasc Med (Hagerstown). 2021;22(3):151-61.

45. US Preventive Services Task Force, Krist AH, Davidson KW, Mangione CM, Barry MJ, Cabana M, et al. Behavioral Counseling Interventions to Promote a Healthy Diet and Physical Activity for Cardiovascular Disease Prevention in Adults with Cardiovascular Risk Factors: US Preventive Services Task Force Recommendation Statement. JAMA. 2020;324(20):2069-75.

46. Deeken JF, Figg WD, Bates SE, Sparreboom A. Toward individualized treatment: predication of anticancer drug disposition and toxicity with pharmacogenetics. Anticancer Drugs. 2007;18:111-26.

47. Backman JT, Luurila H, Neuvonen M, Neuvonen PJ. Rifampin markedly decreases and gemfibrozil increases the plasma concentrations of atorvastatin and its metabolites. Clin Pharmacol Ther. 2005;78:154-67.

48. Lee YJ, Lee MG, Lim LA, Jang SB, Chung JY. Effects of SLCO1B1 and ABCB1 Genotypes on the Pharmacokinetics of Atorvastatin and 2hydroxyatorvastatin in Healthy Korean Subjects. Int J Clin Pharmacol Ther. 2010;48(1):36-45.

49. Nguyen HN, Fujiyoshi A, Abbott RD, Miura K. Epidemiology of Cardiovascular Risk Factors in Asian Countries. Circ J. 2013;77(12):2851-9.

50. de Keyser CE, Peters BJ, Becker ML, Visser LE, Uitterlinden AG, Klungel OH, et al. The SLCO1B1 c.521T>C polymorphism is associated with dose decrease or switching during statin therapy in the Rotterdam Study. Pharmacogenet Genomics. 2014:24(1):43-51.

51. Lee HK, Hu M, Lui S, Ho CS, Wong CK, Tomlinson B. Effects of polymorphisms in ABCG2, SLCO1B1, SLC10A1 and CYP2C9/19 on plasma concentrations of rosuvastatin and lipid response in Chinese patients. Pharmacogenomics. 2013;14(11):1283-94.

\section{Publisher's Note}

Springer Nature remains neutral with regard to jurisdictional claims in published maps and institutional affiliations.

Ready to submit your research? Choose BMC and benefit from:

- fast, convenient online submission

- thorough peer review by experienced researchers in your field

- rapid publication on acceptance

- support for research data, including large and complex data types

- gold Open Access which fosters wider collaboration and increased citations

- maximum visibility for your research: over $100 \mathrm{M}$ website views per year

At $\mathrm{BMC}$, research is always in progress.

Learn more biomedcentral.com/submission 